\title{
Several new data from Poland on the occurrence of imagines of the hypodermatid and oestrid flies (Diptera: Hypodermatidae and Oestridae)
}

\author{
Agnieszka DrABER-MOŃKO $^{1}$ and Cezary BYSTROWSKI ${ }^{2}$ \\ ${ }^{1}$ Museum and Institute of Zoology, PAS, Wilcza 64, 00-679 Warszawa, Poland; e-mail: draber@miiz.waw.pl \\ ${ }^{2}$ Forest Research Institute, ul. Braci Leśnej 3, Sękocin Stary, 05-090 Raszyn, Poland; \\ e-mail: C.Bystrowski@ibles.waw.pl
}

\begin{abstract}
The paper reports on new records of representatives of the families Hypodermatidae and Oestridae collected as imagines in Poland in 1996-2006. The data are supplemented with observations on the behaviour of imagines and information concerning their world distribution and known hosts. The paper contains color photographs of three species: Hypoderma Diana, Cephenemyia ulrichii and Pharyngomyia picta.
\end{abstract}

Key words: Diptera, Hypodermatidae, Oestridae, occurrence, observations of adult flies, new data

\section{INTRODUCTION}

Flies of the superfamily Oestroidea are very important in medical and veterinary sciences. Adults often are known to be important from medical and veterinary point of view and have an impact by causing myiasis in humans and livestock (Greenberg 1973, Zumpt 1965). Adults of Oestroidea are aphagic (their mouthparts are rudimental) and therefore mostly short living: only inseminated females of bot-flies spend about three weeks motionless in crevices of walls or other hiding places (Colwell et al. 2006). During this time the developing larvae become full-grown and in the favourable weather are injected into the nostrils or eyes of the host animal (Draber-Mońko 1978). All members of family Oestridae develop in the nasopharyngeal cavities, mainly of Perissodactyla and Artiodactyla. The gravid flies swarm around the heads of the animals, and deposit the larvae into the nostrils and sometimes also into the orbits. The Hypodermatidae are dermal parasites and their usual hosts are the Artiodactyla, Lagomorpha and Rodentia (Zumpt 1965). A complex of pathologic changes caused by larvae of Diptera, which not only invade their host organism but even migrate within it (so-called myiases), most frequently result from infestation by larvae of Oestroidea belonging to the families: Gasterophilidae, Hypodermatidae and Oestridae. Some of them (eg. Hypoderma, Gasterophilus) belong to obligatory parasites with a fairly limited specificity and associated mainly with one type of host, e.g. Hypoderma bovis (L.) with cattle. These parasites are rarely found in other animals or in man (Draber-Mońko 2001). Nevertheless, the invasion of Hypoderma bovis (L.) - a typical parasite of cattle - in a non-specific host, domestic horse Equus c. caballus L., has been recently reported (Basiaga et al. 2014) in Poland, and the references therein show rather wide spectrum of similar cases. Behaviour of accidental parasites in humans is different from that in their specific host: the larvae usually do not complete their development, causing nevertheless frequently serious disorder in the invaded organism (Stojałowska \& Gieryng 1981).

The taxonomic placement and scope of the three groups of bot-flies - Gasterophilidae, Hypodermatidae and Oestridae - have been variously interpreted. Some dipterologists (Minár 
2000, Lucientes 2002, Nartshuk 2003) treat them as separate families in Calyptratae, others (Wood 1987, Pape 2005) as subfamilies (Gasterophilinae, Hypodermatinae and Oestrinae) within single family Oestridae. Trojan (2007) in Fauna Polski accepted (with minor modifications) Schumann's (1992) concept of a superfamily Oestroidea containing Gasterophilidae, Hypodermatidae and Oestridae as families - this classification is followed also herein. Hypodermatidae are represented in Poland by four species, and Oestridae by six.

In Poland, like elsewhere, larvae of bot-flies are much more frequently found than imagines, so any new records of adult forms should be carefully recorded. Despite faunistic data from XIX and XX centuries, concerning bot-flies in Poland, having been partly verified by Draber-Mońko (1974, 1978, 1981, 2007a, b, c), the distribution of this group in Poland remains poorly known.

The present paper aims to summarize the records, known to us, of adult stages of Hypodermatidae and Oestridae collected in Poland during the last two decades.

\section{MATERIAL AND METHODS}

The hypodermatid and oestrid flies were collected in Poland during four seasons: 1998, 2013, 2015 and 2016. Detailed information concerning localities of collected material are presented below:

Krynicki Grąd Mały [5315'47"N, 22³6'34"E] - mineral elevation at the south-eastern edge of Bagno Lawki (southern part of Biebrza River catchment), on the western side of the Strękowa Góra - Osowiec road): bushy fen with Betula pubescens and Alnus glutinosa, ca. 200 m. to the west of oak-hornbeam forest (Fig. 1).

Forestry Krwony (Forest Inspectorate Turek) [5202'50"N, 18³8'40"E] - flies were collected at morning, ca. 9 a.m., on sandy road along high voltage line, among pine stands on coniferous habitats. The area under the power line was sparsely grown with junipers, some pine sprouts and birches, with extensive surfaces dominated by heather.

Village Stara Kaźmierka (comm. Chocz, distr. Pleszew) [5200'08"N, 1750'30"E] young pine growth with dry, sunlit, treeless sandy glades overgrown by thermophilous plants including abundant Helichrysum arenarium; the area surrounded by pine forest with rich undergrowth. Flies were caught in white Moericke traps.

Village Pila (comm. Chocz, distr. Pleszew) [515'여"N, 1755'08"E] - sandy wastelands at the edge of pine forest; one specimen singled out.

Village Żbiki (comm. Czermin, distr. Pleszew) [5159'04"N, 17²7'17"E] - wastelands at the edge of pine forest with admixture of deciduous trees; sunny place overgrown with numerous species of xerophilous plants (abundant Helichrysum arenarium). Flies caught in white Moericke traps.

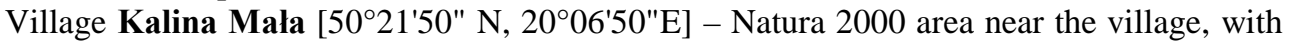
numerous xerotherm slopes separated by forested spaces (Fig. 2). Flies have been collected by sweep-netting of the slope with white entomological net.

Puszcza Białowieska, Forest Inspectorate Hajnówka, sector 443C [5241'53"N, $23^{\circ} 41^{\prime} 09^{\prime \prime E}$ ] - area west of Czerlonka village, crossed by Hajnówka-Białowieża railway (Fig. 3).

The identified specimens have been deposited in the private collection of second author.

The general distribution data are given after Grunin (1955, 1962), Papavero (1977) and Zumpt (1965).

All the photographs were taken with a Nikon SMZ 1500 and set by Cezary Bystrowski using Helicon Focus 5.3. Flies were caught in white Moericke traps, sweep-netted or singled out with white entomological net. 

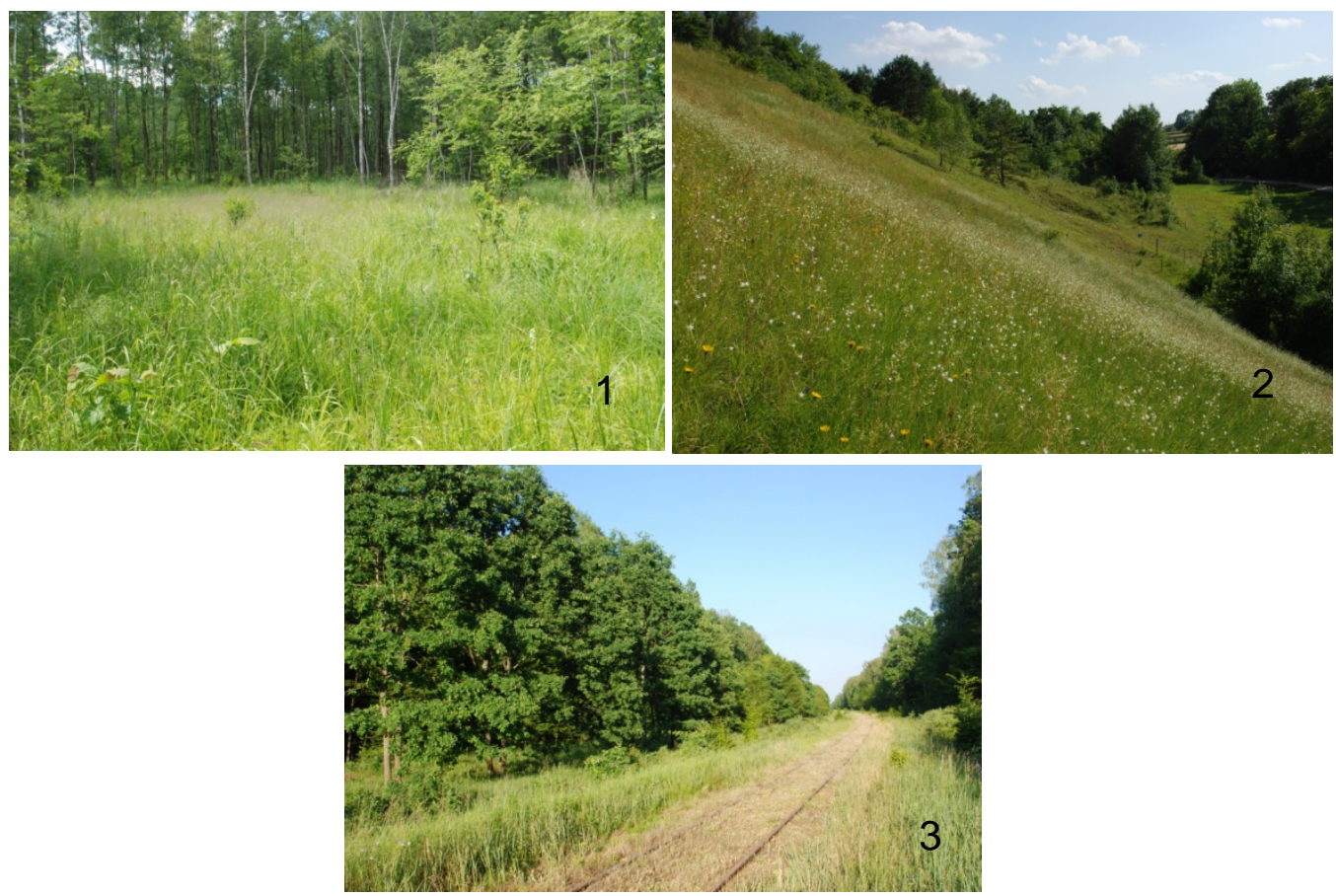

Figs 1-3. The habitats. 1 - Krynicki Grąd Mały, bushy fen; 2 - Kalina Mała, xerotherm slope, 3 - Puszcza Białowieska, Hajnówka, sector 443 C, edge of oak-hornbeam forest and railway line. Photos by C. Bystrowski.

\section{SYSTEMATIC REVIEW OF SPECIES}

Superfamily Oestroidea

Family Hypodermatidae

Tribe Hypodermatini

Hypoderma Latreille, 1818

\section{Hypoderma diana Brauer, 1858}

(Figs 4-8)

Hypoderma diana Brauer, 1858: 397. Type locality: Austria "Wildprater”

Material examined. Nizina Wielkopolsko-Kujawska, distr. Turek, forestry Krwony [UTM CC37], 17 May 2013, 8 males, leg. et det. C. Bystrowski. Distr. Pleszew, village Stara Kazimierka [UTM XT96], 6 May 2013, 1 female, leg. P. Żurawlew, det. C. Bystrowski; 20 May 2013, 1 female, leg. P. Żurawlew, det. C. Bystrowski; 2 Jun 2013, 1 female, leg. P. Żurawlew, det. C. Bystrowski; distr. Pleszew, village Żbiki [UTM XT96], 18 May 2016, 1 female, collected to white Moericke trap, leg. P. Żurawlew, det C. Bystrowski; distr. Pleszew, village Piła [UTM YTO5], 5 May 2015, 1 female, leg. E. Markiewicz, det. C. Bystrowski. Wyżyna Krakowsko-Wieluńska, distr. Miechów, village Kalina Mała [UTM DA38], 23 Apr 2015, 1 female, leg. et det. C. Bystrowski. 

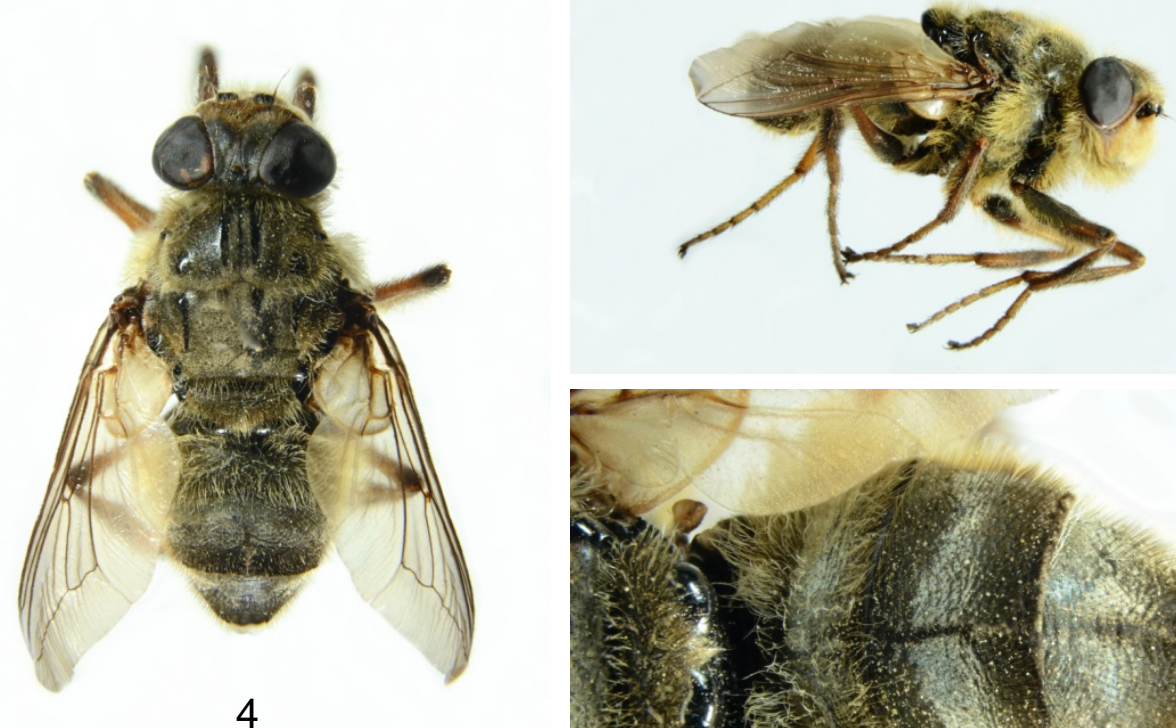

5
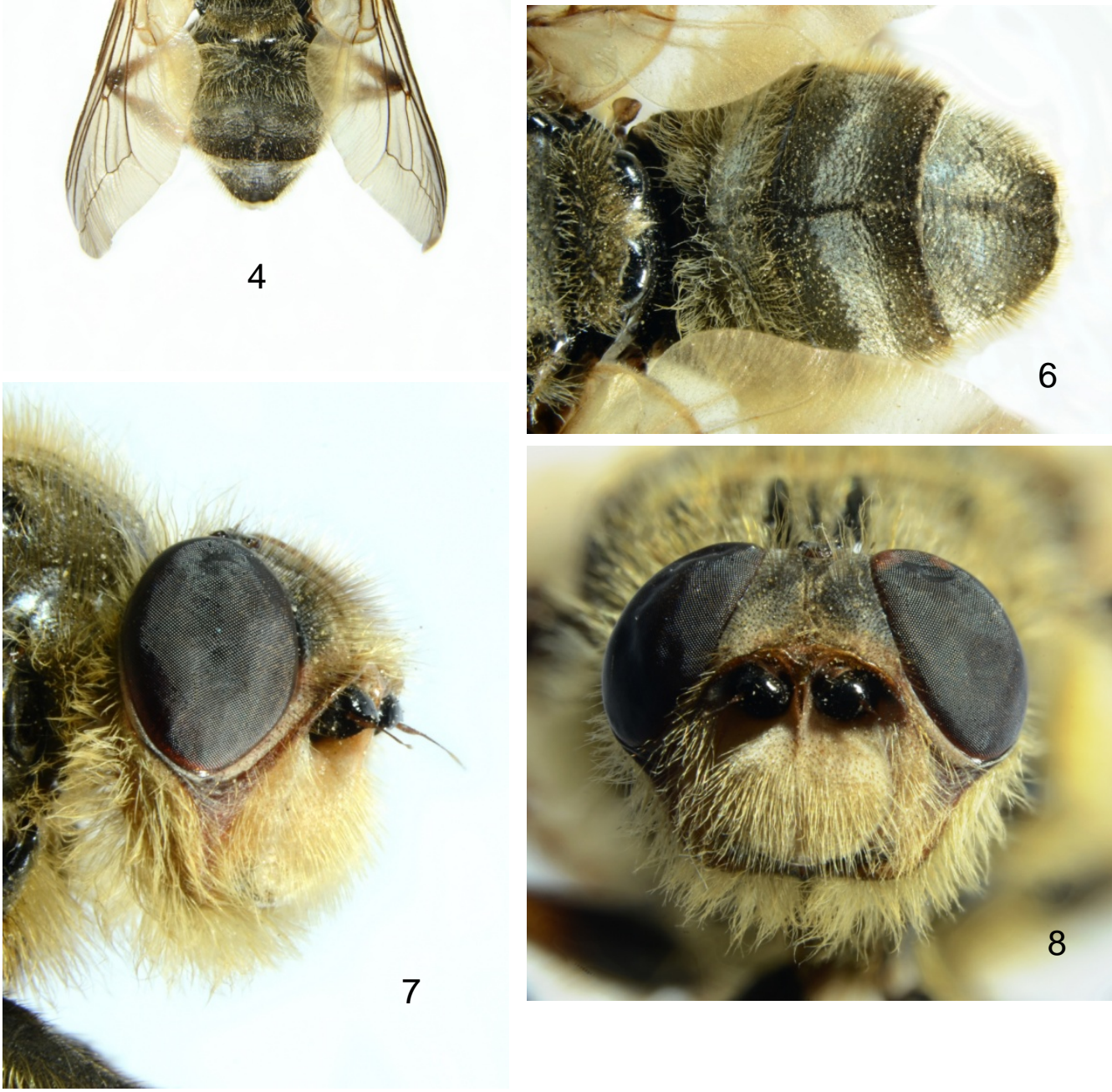

Figs 4-8. Hypoderma diana Brauer, male, distr. Turek, Forestry Krwony, 17 May 2013, leg. et det. C. Bystrowski; $4-$ habitus in dorsal view 5 - habitus in lateral view, 6 - abdomen and scutellum in dorsal view, 7 - head in lateral view, 8 - head in frontal view. Photos by C. Bystrowski. 
Remarks. Two aspects of the species behaviour deserve notice. (1) Males were observed and caught by the second author on ground of sandy road. They sat singly by several to more than ten meters apart, resembling territorial behaviour of many other insects like males of some butterflies or dragonflies, while females were attracted by white colour of Moericke traps (P. Żurawlew, pers. comm.), perhaps in connection with pale colouration of the species' main host, C. capreolus, to which females might be particularly sensitive. Both information may provide interesting guide to effective collecting. (2). Males sitting on sandy ground deceptively resembled Tachina ursina Meigen (Diptera, Tachinidae). They were caught by covering with entomological net.

Distribution. According to Grunin (1962), who published a distribution map, H. diana Br. occurs from Western Europe across Central Asia to the Far East, between 30 and 60 degrees of latitude (Zumpt 1965).

In Poland, imagines of this species have been reported from Pojezierze Pomorskie, Nizina Wielkopolsko-Kujawska, Nizina Mazowiecka, Podlasie, Wyżyna Małopolska, Śląsk Dolny and Sudety Zachodnie (Draber-Mońko 1974, 1978), as well as Wyżyna Krakowsko-Wieluńska.

Hosts. The main host of $H$. diana Br. is Capreolus capreolus (L.). However, this warble fly is not very host-specific, and infestations have also been found in the following Cervidae and Bovidae: Cervus elaphus L., Cervus nippon Temm., Dama dama (L.), Alces alces (L.), Rangifer tarandus (L.), Rupicapra rupicapra (L.) and Ovis musimon (Pallas) (Zumpt 1965).

\section{Family Oestridae}

Subfamily Cephenemyiinae

Cephenemyia Latreille, 1818

\section{Cephenemyia ulrichii (Brauer, 1862)}

(Figs 9-11)

Cephenemyia ulrichii Brauer, 1862: 974. Type locality: "Ibenhorst”

Material examined. Podlasie, Biebrzański Park Narodowy, distr. Trzcianne, Krynicki Grąd Mały [UTM FE00], 10 Jun 1998, 1 female, leg. et det. C. Bystrowski.

Remarks. The fly has been collected on bushy fen with Betula pubescens and Alnus glutinosa, ca. $200 \mathrm{~m}$ west of oak-hornbeam forest, in the proximity of startled female elk.

Distribution. Central and Nord Europe, Far East (Papavero 1977, Nilssen et al. 2008). The distribution of this species does not seem to coincide with that of its host (Papavero 1977).

In Poland the imagines of the species were found on Pojezierze Mazurskie (Draber-Mońko 1974), and now on Podlasie.

Hosts. C. ulrichii (Br.) is a specific parasite of elk Alces alces (L.) (Papavero 1977), other host reported is Capreolus capreolus (L.) (Nilssen et al. 2008).

Pharyngomyia Schiner, 1861

\section{Pharyngomyia picta (Meigen, 1824)}

(Figs 12-16)

Oestrus picta Meigen, 1824: 172. Type locality: “Oesterreich”

Material examined. Puszcza Białowieska, distr. Hajnówka, Forest Inspectorate Hajnówka, sector 443 C [UTM FD84], 6 Aug 2015, 1 female, leg. et det. C. Bystrowski.

Remarks. The fly - a female hovering around the second author - has been caught on the edge of deciduous (oak-hornbeam) forest and railway line, among low hornbeam re-growth. 
Distribution. Eurasia, Far East (coinciding with the distribution of Cervus elaphus L. and Cervus nippon Temm.) (Papavero 1977).

In Poland imagines were found on Pojezierze Pomorskie, Pojezierze Mazurskie, Nizina Mazowiecka (Draber-Mońko 1978, 1981) and now in Puszcza Białowieska.

Hosts. The main host is Cervus elaphus L.; other hosts reported are: Cervus nippon Temm., Dama dama (L.), Alces alces (L.) and Capreolus capreolus (L.) (Papavero 1977).

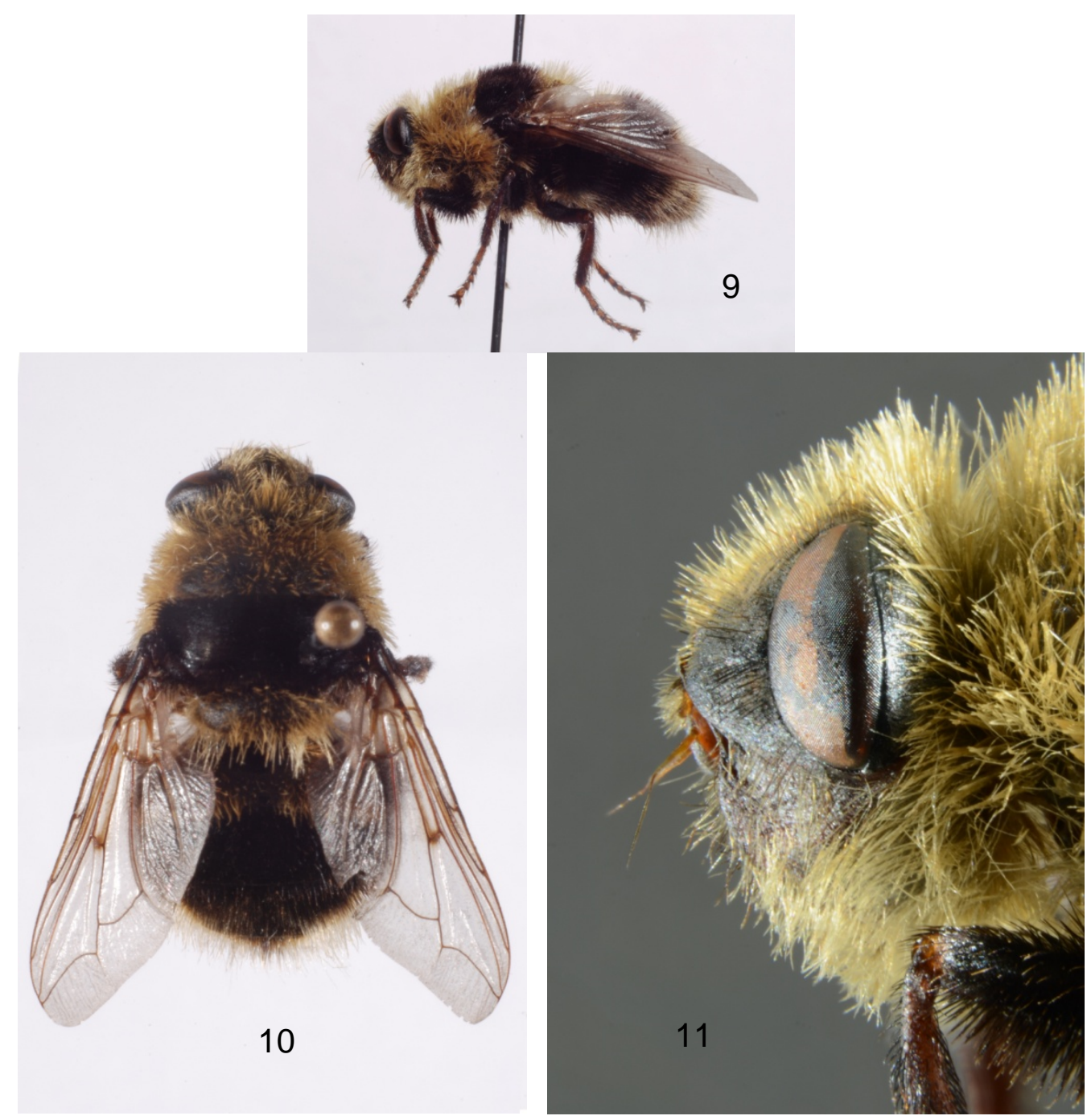

Figs 9-11. Cephenemyia ulrichii (Brauer), female, Biebrzański Park Narodowy. Krynicki Grąd Mały, 10 Jun 1998, leg. et det. C. Bystrowski; 9 - habitus in lateral view, 10 - habitus in dorsal view, 11 - head and anterior part of thorax in lateral view. Photos by C. Bystrowski. 

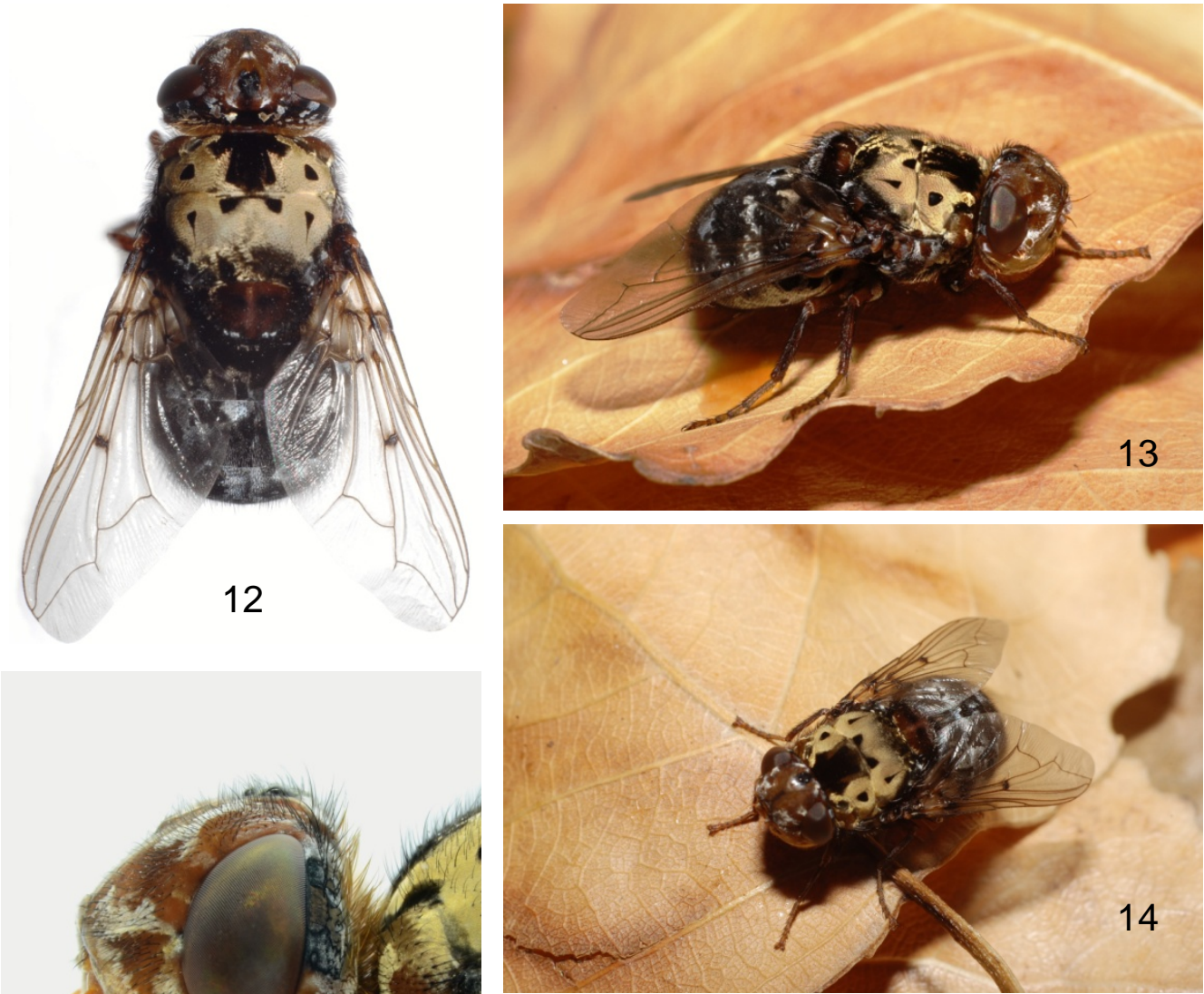

15

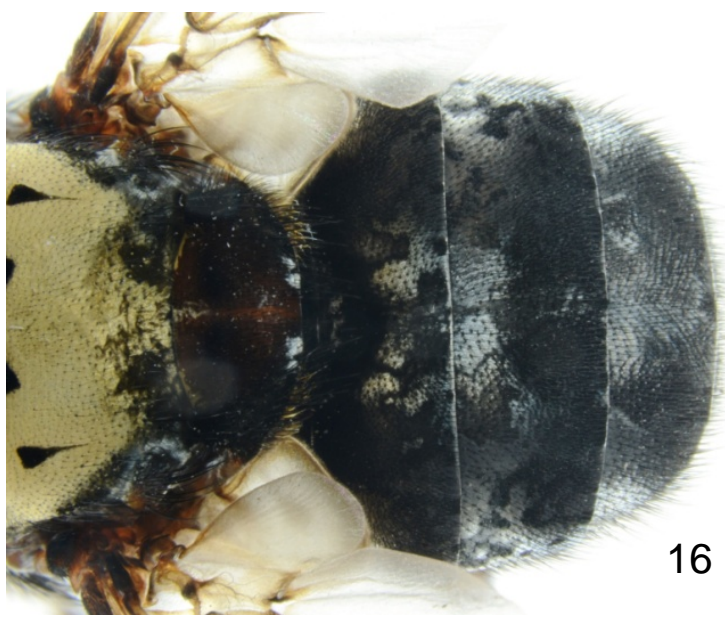

Figs 12-16. Pharyngomyia picta (Meigen), female, Puszcza Białowieska, Forest Inspectorate Hajnówka, sect. 443 C, 6 Aug 2015, 1- female, leg. et det. C. Bystrowski; 12 - habitus in dorsal view, 13 - habitus in laterodorsal view, 14 habitus in anterodorsal view, 15 - head in lateral view, 16 - abdomen, scutellum and posterior part of thorax in dorsal view. Photos by C. Bystrowski. 


\section{DISCUSSION}

Poland lies well within the outlined distribution areas, what suggests that the occurrence of these flies in our country is only dependent upon finding an appropriate host. Some earlier publications questioned this opinion - e.g. Papavero (1977) adduced the alleged absence of Cephenemyia ulrichii (Brauer), a specific parasite of elk, in Sweden - however, in 2008 this species was recorded from there (Nilssen et al. 2008).

The presented data show that these flies are not so rare as it would seem, although imagines are seldom caught. The apparent rarity of adult Oestroidea in semi-natural habitats may be partly explained by aphagy and resulting short life span of adult stage: larvae of various bot-fly species are more frequently found in domestic animals and fallow-deer (at slaughter).

In this context, the authors wish to draw attention to the fact that several females of Hypoderma diana cought up in traps of bright color in young pine forest (white Moericke traps, clearly visible in forest) what can be associated with specific behavior of the females during a searching of their hosts. If females of $H$. diana are really attracted by the small bright objects in forest, this observation may carry some further implications. Perhaps the use of Moerick'e traps can be applied to a methodology for collecting these species, or even to estimating the relative abundance of $H$. diana in the examined area. The existence of a such specific behavior (ie. a female lured by the bright spots in the forest), in helping the female find a host (ie. a deer), joins that parasitoid to a particular host, in principle by the characteristic features of its external appearance: white spot in the rear part of the body. The impact of such behavioral links are poorly understood for this group of flies, although it is highly probable that this mechanism also occurs in the other horsefly species. This type of behavioral relationship is likely not always effective, given increasing reports of hypodermatid and oestrid flies on nonspecific hosts.

\section{ACKNOWLEDGEMENTS}

The authors would like to express thanks to Przemysław Żurawlew from Żbiki near Pleszew for forwarding collected material of Hypoderma diana. We are indebted to reviewers for their valuable suggestions.

\section{REFERENCES}

BASIAGA M., KoRnaŚ S., Kowal J. \& Nosal P. 2014. Hypoderma sp. - rzadki, nietypowy pasożyt koni. Roczniki Naukowe Polskiego Towarzystwa Zootechnicznego 10: 161-168.

Colwell D. G., Hall M. J. R. \& Scholl P. J. 2006. The Oestrid Flies: Biology, Host- Parasite Relationships, Impact and Management. CABI Publishing, Wallingford, 360 pp.

Draber-MoŃKO A. 1974. Materiały do znajomości Gasterophilidae, Hypodermatidae i Oestridae (Diptera) Polski. Fragmenta Faunistica 20: 1-13.

DrABER-MoŃKO A. 1978. Gzy (Diptera: Gasterophilidae, Hypodermatidae i Oestridae) pasożyty ssaków Polski. Monografie Parazytologiczne 8: 1-274.

DrABER-MoŃKO A. 1981. Gasterophilidae, Hypodermatidae, Oestridae, Hippoboscidae, and Nycteribiidae (Diptera) of Warsaw and Mazovia. Memorabilia Zoologica 35: 163-168.

Draber-MońKo A. 2001. Muszyca (myiosis) u człowieka. In: A. BuczeK \& Cz. BŁASZAK (ed.), Stawonogi pasożyty i nosiciele. Lublin. pp 215-228.

DraBer-MoŃKO A. 2007a. Gzy żołądkowe (Gasterophilidae), pp. 160-163, 240. In: BogdANOWICZ W., CHUDZICKA E., PILIPIUK I. \& SKIBIŃSKA E. (eds.). Fauna Polski - charakterystyka i wykaz gatunków [Fauna of Poland characteristics and checklist of species]. Muzeum i Instytut Zoologii PAN, Warszawa, 2, 506 pp.

DRABER-MoŃKo A. 2007b. Gzy podskórne (Hypodermatidae), pp. 163-166, 240. In: BogDANOWICZ W., CHUDZICKA E., PILIPIUK I. \& SKIBIŃSKA E. (eds.). Fauna of Poland - characteristics and checklist of species. Muzeum i Instytut Zoologii PAN, Warszawa, 2, 506 pp.

DrABER-MoŃKO A. 2007c. Strzykacze (Oestridae), pp. 166-169, 240. In: BogdANOwicz W., ChudZiCKA E., PILIPIUK I. \& SKIBIŃSKA E. (eds.). Fauna Polski - charakterystyka i wykaz gatunków [Fauna of Poland characteristics and checklist of species]. Muzeum i Instytut Zoologii PAN, Warszawa, 2, 506 pp. 
GreenberG B. 1973. Flies and desease. Vol. 2. Biology and desease transmission. Princeton University Press, Princeton, XII+448 pp.

GRUNIN K. JA. 1955. Želudočnyje ovody (Gasterophilidae). Fauna SSSR, N. S. Vol.17: 1-96. Moskva-Leningrad.

GRUNIN K. JA. 1962. Podkožnye ovoda (Hypodermatidae). Fauna SSSR, N.S. 82. Nasekomye dvukrylye, 19, Vol. 4: 1-238. Zoologičeskij Institut AN SSSR, Moskva-Leningrad.

LUCIENTES J. 2002. Hypodermatidae. In: CARLES-TORÁ M. \& ANDERSEN H. (eds), Catalogo de los Diptera de España, Portugal y Andorra (Insecta). Monografias S. E. A., 8: 209.

MinÁř J. 2000. Family Hypodermatidae. In: PAPP L. \& DARVAS B. (eds). Contributions to a Manual of Palaearctic Diptera (with special reference to flies of economic importance). Appendix. Science Herald. Budapest: 479-494.

NARTSHUK E. P. 2003. Opredelitel' semejstv dvukrylykh nasekomykh (Insecta: Diptera) fauny Rossii i sopredel'nykh stran (s kratkom obzorom semejstv mirovoj fauny). Trudy Zoologičeskogo Instituta RAN. 294: 1-250.

NilsSEN A. C., ISOMURSU M. \& OKSANEN A. 2008. The moose throat bot fly Cephenemyia ulrichii larvae (Diptera: Oestridae) found developing in roe deer (Capreolus capreolus) for the first time. Acta Veterinaria Scandinavica 50: 14 .

PAPAVERO N. 1977. The World Oestridae, Mammals and Continental Drift. Series Entomologica. Vol. 14. W. Junk, The Hague, The Netherlands, VIII +240 pp.

PAPE T. 2005. Oestridae. Fauna Europaea. Available at: http://www.faunaeur.org/full_results.php?id=10932 (30 Sep 2017)

SchumanN H. 1992. Systematische Gliederung der Ordnung Diptera mitbesonderer Berücksichtigung der in Deutschland vorkommenden Familien. Deutsche entomologische Zeitung. (N.F.), 39 (1-3): 103-116.

STOJAŁOWSKA W. \& GIERYNG R. 1981. Nietypowe inwazje pasożytnicze u człowieka. Wiadomości Parazytologiczne 27: 3-16.

Trojan P. 2007. Muchówki, dwuskrzydłe Diptera, pp. 9-14, 79-82. In: BogdanowiCz W., ChudziCKA E., PILIPIUK I. \& SKIBIŃSKA E. (eds), Fauna Polski - charakterystyka [Fauna of Poland - characteristics]. Muzeum i Instytut Zoologii PAN, Warszawa, 2, 505 pp.

Wood D. M. 1987. Chapter 107. Oestridae. In: McAlPine J.F. (ed.), Manual of Nearctic Diptera. Volume 2. pp. 1147-1158. Agriculture Canada Monograph 28: I-VI, 675-1332.

ZUMPT F. 1965. Myiasis in man and animals in the Old Word. London, Butterworths. XV + 267.

\section{STRESZCZENIE}

\section{[Kilka nowych danych z Polski o występowaniu dorosłych postaci gzów poskórnych i strzykaczy (Diptera: Hypodermatidae and Oestridae)]}

Opracowany materiał muchówek z rodzin Hypodermatidae i Oestridae został zebrany w trakcie czterech sezonów: 1998, 2013, 2015 i 2016. Muchówki były zbierane głównie siatką entomologiczną lub czerpakiem, a jedynie okazy Hypoderma diana Brauer. złapały się także w białe pułapki Moericke'a. Zgromadzony materiał liczył 16 okazów. Z rodziny Hypodermatidae wyróżniono jeden gatunek $H$. diana oraz dwa rzadko spotykane gatunki z rodziny Oestridae: Cephenemyia ulrichii (Brauer) i Pharyngomyia picta (Meigen). W opracowaniu zamieszczono nowe obserwacje dotyczące zachowania obu płci gzów oraz informacje dotyczące ich rozmieszczenia i znanych żywicieli. Podsumowano dotychczasowe doniesienia o dorosłych formach przedstawicieli rodzin Hypodermatidae i Oestridae odłowionych w Polsce w ostatnich dwóch dekadach. Gatunki zostały przedstawione na kolorowych fotografiach. 